\title{
Effect of Feeding Garlic (Allium sativum) on Haematological, Serum Biochemical Profile and Carcass Characteristics in Broiler Chicken
}

\author{
Bondona Borgohain, Joga Dev Mahanta, Deben Sapcota, \\ Bornalee Handique* and Rafiqul Islam
}

\author{
College of Veterinary Science, Assam Agricultural University, Khanapara, \\ Guwahati-781022, Assam, India
}

*Corresponding author

\section{Keywords \\ Broiler chicken, \\ Carcass \\ characteristics, \\ Garlic, \\ Haematological, \\ Serum biochemical \\ Article Info \\ Accepted: \\ 07 September 2019 \\ Available Online: \\ 10 October 2019}

\section{A B S T R A C T}

A total of 144 day old broiler chicks (Cobb-400 Y) were randomly distributed into four groups (3 replicates of 12 chicks) using randomization block design viz. $\mathrm{T}_{0}$ contained no garlic powder supplementation while diet $\mathrm{T}_{1}, \mathrm{~T}_{2}$ and $\mathrm{T}_{3}$ contained $0.5,1.0$ and $1.5 \%$ of garlic powder, respectively along with probiotic powder named probios. Haemoglobin, total RBC, Cholesterol, Triglycerides, HDL and LDL were differed significantly $(\mathrm{P}<0.05)$ among different treatment groups. Significantly $(\mathrm{P}<0.05)$ lowest cholesterol was recorded in $T_{3}$ and $T_{2}$ group as compared to $T_{1}$. The per cent yield of cut-up parts like neck, wing, back, breast, thigh, drumstick and relative weight of organs on dressed weight basis did not differ significantly among different treatment groups except the per cent weights of liver, gizzard, lungs and abdominal fat. The study revealed that garlic supplementation in commercial broiler diet reduced serum cholesterol, triglycerides and minimizes excessive fat deposition in broiler carcass.

\section{Introduction}

Broiler farming has emerged as the most profitable business for self employment among the rural society. The fast growing nature of broiler chickens and their short generation interval have been associated over the years with the use of antibiotic growth promoters in animal feeds in order to improve the quality of the product. However, the use of antibiotic based growth promoters is presently facing serious problem and has raised global concern as some reports revealed their ill effects among which are development of microbial resistance to the products and their potential harmful effects on human health (Rahmatnejad et al., 2009). Moreover, antibiotics lead to drug resistance in bacteria 
and drug residues in meat (Issa and Omer, 2012). These lead to the search for alternative substances that eliminate these threats. Probiotics, Prebiotics and medicinal plants as natural feed additives are currently used in poultry diets to enhance the performance and immune response of birds. Garlic (Allium sativum) which belongs to the family Alliaceae and the genus Allium (Eric, 2010) is widely distributed and used in all over the world as a spice and herbal remedy for the prevention and treatment of variety of diseases (Javandel et al., 2008). These functions are mainly attributed to the bioactive components present in garlic (Amagese et al., 2001), which is a sulpher containing organic compound known as diallyl polysulphide which possess antimicrobial activity (Tsao and Yin, 2001) that could be responsible for the growth promoting effects of garlic. Qureshi et al., (1983) concluded that garlic has the tendency to lower serum and liver cholesterol. To enhance the activity of these probiotics, prebiotics are essential. Inulin is present in significant quantities in several vegetables specially garlic. The inulin content of garlic on dry weight basis was reported as $9-16 \%$ (Source: RemadySpot.com).

\section{Materials and Methods}

The experiment was conducted in the experimental poultry shed of Instructional Poultry Farm, College of Veterinary Science, Assam Agricultural University, Khanapara781022. The experimental protocol was approved by the Institutional Animal Ethics Committee (IAEC) with approval No. 770/ac/CPCSEA/FVSc/AAU/IAEC/15-16/349 and carried out as per the guidelines of Committee for the Purpose of Control and Supervision of Experiments in Animals (CPCSEA), Ministry of Environment, Forests and Climate Change, Government of India. A total of 144 day old broiler chicks (Cobb-400 Y) randomly distributed into four groups (3 replicates of 12 chicks) using randomization block design viz. $\mathrm{T}_{0}$ contained no garlic powder supplementation while diet, $\mathrm{T}_{1}, \mathrm{~T}_{2}$ and $\mathrm{T}_{3}$ contained $0.5,1.0$ and $1.5 \%$ of garlic powder, respectively. All the experimental groups $\left(T_{0}, T_{1}, \quad T_{2}\right.$ and $\left.T_{3}\right)$ were fed commercial brand of probiotic powder (Trade name- Probios, manufactured by Stallen South Asia Pvt. Ltd., Thane, Maharastra) at the recommended dose of $1 \mathrm{~g} /$ litre of drinking water. This Probios contained Bifidobacterium bifidum, Lactobacilluc acidophilus, $L$. bulgaricus, L. casei, L. plantarum, L. faecium and Streptococcus thermophilus, yeastTorulopsis spp, Aspergillus coryza. The broiler starter and finisher diets were prepared as per BIS (1992) recommendation. The composition and nutritive value of basal diets are shown in Table 1. All the chicks were given ad libitum access to feed and water. The chicks were vaccinated against Ranikhet disease with Lasota strain (F1) and Infectious Bursal Disease (IBD) vaccine on $7^{\text {th }}$ and $14^{\text {th }}$ day of age, respectively.

At the end of the experiment, six birds from each group were selected for collection of blood sample from the wing vein. For estimation of haematological parameter blood was collected aseptically with anticoagulant and estimated using automatic haematolyzer. For estimation of total serum biochemical profile blood was collected aseptically from the birds. The blood samples were brought to the laboratory without disturbing the clots and centrifuged at $3000 \mathrm{rpm}$ for $15 \mathrm{~min}$. to collect serum and stored at $-20^{\circ} \mathrm{C}$ till further analysis. Serum biochemical profiles were estimated by spectrometric method (dual beam UVSpectrometer) using commercial kits (Coral Clinical System, Uttrakhand, India).

Birds were slaughtered for the carcass parameters at the end of the experimental trial. The birds were fasted overnight and preslaughter weights were recorded. The dressed 
weight of each group was obtained separately after complete bleeding and removal of feathers, viscera, head and legs by keeping the skin intact with the carcass and calculated as percent of pre-slaughter weight. The neck, wing, back, drumstick, thigh and breast meat were weighed seperately and divided by preslaughter weight to determine relative weight and expressed as percentage. Fat around the abdominal wall was removed and weighed and calculated as percentage preslaughter weight. The edible visceral organs (heart, liver and gizzard) and lymphoid organs were weighed individually after separating from viscera. The total weight of small intestine along with caecal content was taken and calculated as percent of pre-slaughter weight.

\section{Results and Discussion}

\section{Haematological parameters}

All the haematological parameters except haemoglobin and total $\mathrm{RBC}$ recorded in the present study differed significantly $(\mathrm{P}<0.05)$ among different treatment groups (Table 2). Contrary to the present result, Ayeni et al., (2008) and Jimoh et al., (2012) stated that haematological parameters were not significantly affected by garlic supplementation of the broilers diets. The PCV percentage recorded in $T_{1}$ and $T_{2}(24.60$ and 24.72) group was significantly $(\mathrm{P}<0.05)$ higher as compared to $\mathrm{T}_{0}$ group (21.54). This result corroborated with the findings of Elagib et al., (2013) who found numerically higher PCV values (24.00 and 23.70) in garlic treated groups as compared to control (22.00). The total WBC, WBC differential count (Neutrophil, Eosinophil, Monocyte and Lymphocyte) recorded in the present study was significantly $(\mathrm{P}<0.05)$ higher in $\mathrm{T}_{2}$ and $\mathrm{T}_{3}$ groups as compared to $\mathrm{T}_{0}$ and $\mathrm{T}_{1}$ group. Contrary to the present results, Elagib et al., (2013) found no significant effect $(\mathrm{P}>0.05)$ on the differential count of WBC in broiler chicken supplemented with 3 and 5 per cent of garlic powder in feed. Fadlalla et al., (2010) who reported significantly $(\mathrm{P}<0.05)$ higher total WBC (820.50 million $\left./ \mathrm{mm}^{3}\right)$ in garlic treated $(0.3 \%)$ groups as compared to control.

\section{Serum biochemical parameters}

The mean values of ALT, total serum cholesterol, triglycerides, HDL and LDL except serum glucose were differed significantly $(\mathrm{P}<0.001)$ among different experimental groups (Table 3). The total serum cholesterol was significantly lowest in $\mathrm{T}_{3}$ and $\mathrm{T}_{2}(109.48$ and $110.89 \mathrm{mg} / \mathrm{dl})$ as compared to $\mathrm{T}_{0}$ and $\mathrm{T}_{1}$ group (165.01 and $146.48 \mathrm{mg} / \mathrm{dl}$ ). These results agreed with Prasad et al., 2009 and Issa and Omer, 2012 who reported that dietary supplementation of garlic powder at different concentrations caused a significant decrease in the mean values of total cholesterol, LDL and Triglycerides while HDL was significantly increased in broiler chicken up to 8 weeks of age in comparison to control group. This might be due to possible mechanisms of hypocholesterolaemic and hypolipidemic action of garlic which depresses the hepatic activities of lipogenic and cholesterogenic enzymes such as malic enzyme, fatty acid synthase, glucose-6-phosphatase dehydrogenase (Qureshi et al., 1983 and Chi et al., 1982) and 3-hydroxyl-3-methylglutaryl-CoA (HMG-CoA) reductase (Qureshi et al., 1983).

\section{Carcass characteristics}

\section{Carcass quality trait}

All carcass quality traits (live weight, dressed weight, dressing percentage and giblet weight) except giblet yield percentage recorded in the present study did not differ significantly $(\mathrm{P}<0.05)$ among different treatment groups (Table 4). These findings were in agreement 
with the reports of Javandel et al., (2008), Amouzmehr et al., (2013) and Kharde and Soujanya (2014), who reported that supplementation of garlic had no significant effects on major carcass characteristics including the dressing percentage. However Raeesi et al., (2010) and Eltazi et al., (2014) found significant differences in carcass traits including the dressing percentage in broiler chicken due to supplementation of garlic powder in feed.

\section{Cut up parts}

The per cent yield of cut-up parts like neck, wing, back, breast, thigh and drumstick did not differ significantly (P>0.05) among different treatment groups (Table 5). Similar observations were reported by Amouzmehr et al., (2013) and Milosevic et al., (2013) who found no significant differences in the per cent yield of drumstick, breast and thigh among the control and garlic fed treated groups. Contrary to the present findings, Ademola et al., (2004) found significant $(\mathrm{P}<0.05)$ differences in weights of wing and drumstick among different treatment groups. Raeesi et al., (2010) also found significant $(\mathrm{P}<0.05)$ differences in per cent yield of thigh and breast among the control and garlic treated groups.

\section{Relative organ weights}

The mean per cent weights of relative organs on Dressed Weight Basis (DWB) under different treatment groups are presented in Table 6. The per cent weights of relative organs of broiler chicken on dressed weight basis did not differ significantly $(\mathrm{P}>0.05)$ among different treatment groups except the per cent weights of liver, gizzard, lungs and abdominal fat. The per cent weights of liver, gizzard, lungs and abdominal fat of $\mathrm{T}_{0}$ group $(2.41, \quad 2.48, \quad 0.97 \quad 1.31$ per cent $)$ were significantly $(\mathrm{P}<0.05)$ higher than the garlic fed groups. This implies that this level is appropriate for the birds and that the test diets did not contain any appreciable toxin.

According to Bone (1979) abnormalities in the weights of the internal organs like liver, kidney and gizzard arise because of increased metabolic rate of the organs in attempt to reduce toxic elements or anti-nutritional factors to non-toxic metabolites. Garlic fed bird exhibited higher liver mass as compared to control group. Onibi et al., (2009) in their study on the effect of garlic on performance and meat quality of the broiler chicken found that organ characteristics of chicken were not significantly affected $(\mathrm{P}>0.05)$ by dietary supplementation but abdominal fat contents were numerically lowered due to supplementary garlic.

Contrary to the present findings, Fayad et al., (2011) and Issa and Omer, (2012) found no significant differences in per cent yield of gizzard among different treatment groups. Similar to the present finding, Ademola et al., (2004) also found significant $(\mathrm{P}<0.05)$ differences in the mean weights of liver and lungs due to supplementation of garlic powder in feed.

In the present findings, it was observed that the garlic supplement elicited significant $(\mathrm{P}<0.05)$ decrease of the abdominal fat content of the experimental birds of $T_{1}, T_{2}$ and $T_{3}$ group as compared to control group. The present findings corroborated with the reports of Raeesi et al., (2010), Jimoh et al., (2012) and Oleforuh-Okoleh et al., (2014) who found significant $(\mathrm{P}<0.05)$ depression of weights of abdominal fat in carcasses of broiler chicken supplemented with garlic powder in feed. The reduction in the percentage of abdominal fat in garlic supplemented powder may be attributed to the action of garlic which has been reported to possess lipid lowering effects (Agarwal, 1996). 
Table.1 Percent ingredient and nutrient composition of the experimental basal diet

\begin{tabular}{|c|c|c|}
\hline Ingredients (kg) & Starter (0-28 days) & Finisher (29-42 days) \\
\hline \multicolumn{3}{|c|}{ Percent Ingredient Composition } \\
\hline Maize & 42.0 & 50.5 \\
\hline Rice polish & 14.0 & 15.0 \\
\hline Ground nut cake & 25.0 & 16.0 \\
\hline Soyabean meal & 10.0 & 10.5 \\
\hline Fish meal & 7.0 & 6.0 \\
\hline Mineral mixture & 1.5 & 1.5 \\
\hline Common salt & 0.5 & 0.5 \\
\hline \multicolumn{3}{|c|}{ Nutrient compositionon DM basis (\%) } \\
\hline Dry matter (\%) & 88.92 & 88.95 \\
\hline Crude protein (\%) & 23.04 & 20.12 \\
\hline Ether Extract (\%) & 4.89 & 5.01 \\
\hline Crude Fibre (\%) & 5.81 & 6.11 \\
\hline Nitrogen free extract $(\%)$ & 59.44 & 60.52 \\
\hline Total ash $(\%)$ & 7.01 & 6.98 \\
\hline Metabolizable energy (kcal/kg)* & 2850.85 & 2913.41 \\
\hline
\end{tabular}

*Calculated values

(N.B. Vitamin premix (Vitablend vit $\mathrm{A}, \mathrm{B}_{2}, \mathrm{D}_{3}, \mathrm{~K}$ ) was added @ $20 \mathrm{~g}$ per quintal of diet in both starter and finisher diet. Mineral mixture contained calcium 25\%, Phosphorus 5\%, Sodium chloride 23\%, Iodine $10 \mathrm{ppm}$, Copper 100 ppm, Manganese 2000 ppm and Cobalt 10 ppm).

Table.2 Effect of feeding Garlic (Allium sativum) on haematological parameters in commercial broiler chicken

\begin{tabular}{|c|c|c|c|c|c|}
\hline Parameters & $\begin{array}{c}\text { T0 } \\
\text { (Control) }\end{array}$ & $\begin{array}{c}\mathrm{T}_{1} \\
(\mathrm{GP}-0.5 \%)\end{array}$ & $\begin{array}{c}\mathbf{T}_{2} \\
\text { (GP-1.0\%) }\end{array}$ & $\begin{array}{c}\mathrm{T}_{3} \\
(\mathrm{GP}-1.5 \%)\end{array}$ & P value \\
\hline Haemoglobin (g/dl) & $9.60 \pm 0.32$ & $10.12 \pm 0.31$ & $10.50 \pm 0.39$ & $9.74 \pm 0.38$ & NS \\
\hline $\operatorname{PCV}(\%)$ & $21.54^{\mathrm{a}} \pm 0.63$ & $24.60^{b} \pm 0.75$ & $24.72^{\mathrm{bc}} \pm 1.24$ & $23.20^{\mathrm{abc}} \pm 0.68$ & * \\
\hline Total RBC (million/ $\mathrm{mm}^{3}$ ) & $2.11 \pm 0.05$ & $2.12 \pm 0.05$ & $2.10 \pm 0.06$ & $2.03 \pm 0.05$ & NS \\
\hline Total WBC (million/ $\mathrm{mm}^{3}$ ) & $71.12^{\mathrm{a}} \pm 1.82$ & $72.52^{\mathrm{ab}} \pm 1.93$ & $85.69^{c} \pm 2.18$ & $85.11^{\mathrm{c}} \pm 1.46$ & $* *$ \\
\hline Neutrophil (million/ $\mathrm{mm}^{3}$ ) & $4.16^{\mathrm{a}} \pm 0.14$ & $4.32^{\mathrm{ab}} \pm 0.13$ & $4.52^{\mathrm{abc}} \pm 0.11$ & $4.69^{c} \pm 0.11$ & $*$ \\
\hline Eosinophil (million/ $\mathbf{m m}^{3}$ ) & $0.52^{\mathrm{a}} \pm 0.07$ & $0.63^{\mathrm{ab}} \pm 0.06$ & $0.76^{\mathrm{c}} \pm 0.09$ & $0.89^{c} \pm 0.09$ & $*$ \\
\hline Monocyte (million/ $\mathrm{mm}^{3}$ ) & $0.91^{\mathrm{a}} \pm 0.03$ & $0.99^{\mathrm{ab}} \pm 0.03$ & $1.08^{c} \pm 0.06$ & $1.12^{\mathrm{c}} \pm 0.03$ & $* *$ \\
\hline Lymphocyte (million/ $\mathrm{mm}^{3}$ ) & $64.19^{a} \pm 1.78$ & $66.26^{\mathrm{ab}} \pm 1.65$ & $70.58^{c} \pm 1.00$ & $71.89^{c} \pm 0.97$ & $* *$ \\
\hline
\end{tabular}

${ }^{\mathrm{abc}}$ Mean values with different superscripts within row differ significantly.

** Significant at $\mathrm{P}<0.001$; *Significant at $\mathrm{P}<0.05$; NS- Non Significant at $\mathrm{P}>0.05$ 
Table.3 Effect of feeding Garlic (Allium sativum) on serum biochemical profile in commercial broiler chicken

\begin{tabular}{|c|c|c|c|c|c|}
\hline Parameters & $\begin{array}{c}\text { T0 } \\
\text { (Control) }\end{array}$ & $\begin{array}{c}\mathrm{T}_{1} \\
(\mathrm{GP}-0.5 \%)\end{array}$ & $\begin{array}{c}\mathbf{T}_{2} \\
(\mathrm{GP}-1.0 \%)\end{array}$ & $\begin{array}{c}\mathbf{T}_{3} \\
(\mathrm{GP}-1.5 \%)\end{array}$ & $P$ value \\
\hline Serum glucose & $248.20 \pm 8.62$ & $243.00 \pm 6.82$ & $247.00 \pm 1.09$ & $244.20 \pm 2.78$ & NS \\
\hline ALT (U/ml) & $26.29^{a} \pm 0.74$ & $26.02^{\mathrm{ab}} \pm 0.39$ & $23.27^{c} \pm 0.55$ & $25.32^{\mathrm{ab}} \pm 0.31$ & * \\
\hline $\begin{array}{c}\text { Total } \\
\text { cholesterol } \\
(\mathrm{mg} / \mathrm{dl})\end{array}$ & $165.01^{\mathrm{a}} \pm 2.66$ & $146.48^{\mathrm{b}} \pm 6.65$ & $110.89^{c} \pm 2.25$ & $109.48^{c} \pm 2.23$ & $* *$ \\
\hline $\begin{array}{c}\text { Triglycerides } \\
\text { (mg/dl) }\end{array}$ & $103.74^{\mathrm{a}} \pm 2.91$ & $81.84^{b} \pm 2.18$ & $53.74^{c} \pm 2.76$ & $50.43^{c} \pm 3.11$ & $* *$ \\
\hline HDL (mg/dl) & $47.42^{a} \pm 3.99$ & $57.47^{\mathrm{ab}} \pm 10.36$ & $82.02^{c} \pm 3.57$ & $83.13^{c} \pm 3.46$ & $* *$ \\
\hline LDL (mg/dl) & $96.85^{\mathrm{a}} \pm 4.88$ & $61.59^{b} \pm 7.59$ & $18.27^{\mathrm{c}} \pm 3.85$ & $16.21^{\mathrm{c}} \pm 4.31$ & $* *$ \\
\hline
\end{tabular}

${ }^{\text {abc }}$ Mean values with different superscripts within row differ significantly.

** Significant at $\mathrm{P}<0.001$; *Significant at $\mathrm{P}<0.05$; NS- Non Significant at $\mathrm{P}>0.05$

Table.4 Effect of feeding Garlic (Allium sativum) on carcass traits in commercial broiler chicken

\begin{tabular}{|c|c|c|c|c|c|}
\hline Parameters & $\begin{array}{c}\text { T0 } \\
\text { (Control) }\end{array}$ & $\begin{array}{c}\mathbf{T}_{\mathbf{1}} \\
(\mathbf{G P P - 0 . 5 \% )}\end{array}$ & $\begin{array}{c}\mathbf{T}_{\mathbf{2}} \\
(\mathbf{G P - 1 . 0 \% )}\end{array}$ & $\begin{array}{c}\mathbf{T}_{\mathbf{3}} \\
(\mathbf{G P - 1 . 5 \% )}\end{array}$ & $\begin{array}{c}\text { P } \\
\text { value }\end{array}$ \\
\hline Live weight (g) & $1891.25 \pm 53.1$ & $1945.88 \pm 74.05$ & $2084.48 \pm 80.28$ & $2020.25 \pm 82.90$ & NS \\
\hline Dressed weight (g) & $1362.44 \pm 44.2$ & $1388.68 \pm 61.78$ & $1506.38 \pm 62.75$ & $1451.50 \pm 57.61$ & NS \\
\hline Dressing percentage (\%) & $71.98 \pm 0.69$ & $71.27 \pm 0.88$ & $72.19 \pm 0.8$ & $71.89 \pm 0.87$ & NS \\
\hline Giblet weight (g) & $103.60 \pm 3.01$ & $98.50 \pm 3.03$ & $101.75 \pm 3.93$ & $97.9 \pm 3.83$ & NS \\
\hline Giblet yield (\%) & $5.61^{\mathrm{a}} \pm 0.17$ & $5.08^{\mathrm{b}} \pm 0.10$ & $4.88^{\mathrm{bc}} \pm 0.05$ & $4.85^{\mathrm{bc}} \pm 0.09$ & $*$ \\
\hline
\end{tabular}

${ }^{\mathrm{abc}}$ Mean values with different superscripts within row differ significantly.

** Significant at $\mathrm{P}<0.001$; *Significant at $\mathrm{P}<0.05$; NS- Non Significant at $\mathrm{P}>0.05$

Table.5 Effect of feeding Garlic (Allium sativum) on per cent yeild cut up parts in commercial broiler chicken

\begin{tabular}{|c|c|c|c|c|c|}
\hline Parameters & $\begin{array}{c}\text { T0 } \\
\text { (Control) }\end{array}$ & $\begin{array}{c}\mathbf{T}_{\mathbf{1}} \\
(\mathbf{G P - 0 . 5 \% )}\end{array}$ & $\begin{array}{c}\mathbf{T}_{\mathbf{2}} \\
(\mathbf{G P - 1 . 0 \% )}\end{array}$ & $\begin{array}{c}\mathbf{T}_{\mathbf{3}} \\
(\mathbf{G P - 1 . 5 \%})\end{array}$ & P value \\
\hline Neck & $6.32 \pm 0.23$ & $5.93 \pm 0.41$ & $6.39 \pm 0.54$ & $6.10 \pm 0.36$ & $\mathrm{NS}$ \\
\hline Wing & $10.56 \pm 0.25$ & $10.46 \pm 0.48$ & $11.28 \pm 0.51$ & $10.33 \pm 0.31$ & $\mathrm{NS}$ \\
\hline Back & $17.33 \pm 0.69$ & $17.41 \pm 0.62$ & $17.51 \pm 0.81$ & $17.44 \pm 0.49$ & $\mathrm{NS}$ \\
\hline Breast & $32.68 \pm 0.94$ & $32.22 \pm 0.85$ & $32.78 \pm 0.81$ & $32.44 \pm 0.65$ & NS \\
\hline Thigh & $14.52 \pm 0.59$ & $14.56 \pm 0.55$ & $14.72 \pm 0.41$ & $14.69 \pm 0.68$ & NS \\
\hline Drumstick & $12.99 \pm 0.33$ & $13.15 \pm 0.45$ & $13.48^{\mathrm{a}} \pm 0.24$ & $13.35 \pm 0.13$ & NS \\
\hline
\end{tabular}

** Significant at $\mathrm{P}<0.001 ; *$ Significant at $\mathrm{P}<0.05$; NS- Non Significant at $\mathrm{P}>0.05$ 
Table.6 Effect of feeding Garlic (Allium sativum) on per cent weight of relative organs and lymphoid organs (on DWB) in commercial broiler chicken

\begin{tabular}{|c|c|c|c|c|c|}
\hline Parameters & $\begin{array}{c}\mathbf{T}_{0} \\
\text { (Control) }\end{array}$ & $\begin{array}{c}\mathrm{T}_{1} \\
(\mathrm{GP}-\mathbf{0 . 5 \%})\end{array}$ & $\begin{array}{c}\mathbf{T}_{2} \\
(\mathbf{G P}-\mathbf{1 . 0 \%})\end{array}$ & $\begin{array}{c}\mathrm{T}_{3} \\
(\mathrm{GP}-1.5 \%)\end{array}$ & $P$ value \\
\hline Liver & $2.41^{\mathrm{a}} \pm 0.11$ & $2.16^{\mathrm{a}} \pm 0.03$ & $2.07^{b} \pm 0.06$ & $2.09^{b} \pm 0.03$ & * \\
\hline Heart & $0.59 \pm 0.03$ & $0.56 \pm 0.05$ & $0.59 \pm 0.02$ & $0.56 \pm 0.05$ & NS \\
\hline Gizzard & $2.48^{a} \pm 0.09$ & $2.35^{\mathrm{a}} \pm 0.07$ & $2.21^{b c} \pm 0.05$ & $2.19 c \pm 0.05$ & $*$ \\
\hline Head & $3.51 \pm 0.19$ & $3.49 \pm 0.21$ & $3.45 \pm 0.11$ & $3.46 \pm 0.03$ & NS \\
\hline Shank & $4.98 \pm 0.15$ & $5.13 \pm 0.31$ & $5.25 \pm 0.17$ & $5.13 \pm 0.13$ & NS \\
\hline Intestine & $5.94 \pm 0.52$ & $5.81 \pm 0.58$ & $5.87 \pm 0.57$ & $5.87 \pm 0.46$ & NS \\
\hline Lungs & $0.97^{\mathrm{a}} \pm 0.03$ & $0.93^{b} \pm 0.02$ & $0.72^{b} \pm 0.04$ & $0.69^{b} \pm 0.02$ & $* *$ \\
\hline Kidney & $0.25 \pm 0.03$ & $0.30 \pm 0.04$ & $0.28 \pm 0.06$ & $0.27 \pm 0.05$ & NS \\
\hline Pancreas & $0.31 \pm 0.05$ & $0.25 \pm 0.02$ & $0.30 \pm 0.01$ & $0.24 \pm 0.02$ & NS \\
\hline Abdominal fat & $1.31 \pm 0.03$ & $1.22^{b} \pm 0.04$ & $0.71^{\mathrm{c}} \pm 0.02$ & $0.67^{\mathrm{c}} \pm 0.02$ & $* *$ \\
\hline \multicolumn{6}{|c|}{ Lymphoid organs } \\
\hline Spleen & $2.31^{\mathrm{a}} \pm 0.05$ & $2.27^{\mathrm{ab}} \pm 0.04$ & $1.68^{c} \pm 0.07$ & $1.72^{c} \pm 0.07$ & $* *$ \\
\hline Thymus & $5.06 \pm 0.19$ & $5.03 \pm 0.18$ & $5.18 \pm 0.17$ & $5.09 \pm 0.19$ & NS \\
\hline Bursa & $1.28 \pm 0.02$ & $1.28 \pm 0.03$ & $1.24 \pm 0.02$ & $1.27 \pm 0.02$ & NS \\
\hline
\end{tabular}

${ }^{\mathrm{abc}}$ Mean values with different superscripts within row differ significantly.

** Significant at $\mathrm{P}<0.001$; *Significant at $\mathrm{P}<0.05$; NS- Non Significant at $\mathrm{P}>0.05$

\section{Lymphoid organs}

Among the lymphoid organs, both bursa and thymus showed no significant $(\mathrm{P} \geq 0.05)$ difference in per cent weights between the different treatments groups (Table 5). However, the per cent weights of spleen differed significantly $(\mathrm{P}<0.05)$ among different experimental groups. The spleen weight decreased significantly $(\mathrm{P}<0.05)$ in $\mathrm{T}_{2}$ and $\mathrm{T}_{3}$ group as compared to $\mathrm{T}_{0}$ and $\mathrm{T}_{1}$. This might be due to the antimicrobial properties of garlic. The present findings were in agreement with the observations of Elagib et al., (2013) wherein, they found no significant $(\mathrm{P}>0.05)$ difference in both weights of bursa and thymus between different treatment with 3 and $5 \%$ garlic powder and spleen weight decreased significantly $(\mathrm{P}<0.05)$ in garlic treated groups as compared to control. Contrary to the present observation, Raeesi et al., (2010) found significant $(\mathrm{P}<0.05)$ differences in per cent yield of bursa among different treatment groups. However, they reported that the relative weights of spleen were higher in unsupplemented group.

Dietary supplementation of garlic reduced the accumulation of abdominal fat pad and decreased serum cholesterol and triglycerides level in the commercial broilers. Dietary supplementation of garlic exhibited hypocholesterlaemic and hypolipidemic effects on the broiler chicken and could therefore be supplemented in broiler diet to minimize excessive fat deposition in broiler carcass however, further studies are required to ascertain the findings of the present study.

\section{References}

Ademola, S. G., Farinu, G. O., Obe, A. O. A. and Babatunde, G. M. 2004. Growth, haematological and biochemical studies on garlic- and ginger-fed broiler chickens. Moor Journal of 
Agricultural Research. 5: 122-128.

Agarwal, K. C. 1996: Therapeutic actions of garlic constituents. Med. Res. 16: 111124.

Amagese, H., Petesch, B., Matsuura, H., Kasuga, S. and Itakura, Y. 2001. Recent advances on the nutritional effects associated with the use of garlic as a supplement: Intake of garlic and its bioactive components. The Journal of Nutrition. 131: 955S-962S.

Amouzmehr, A., Daster, B., Nejad, J.G., Sung, K.I., Lohakare, J. and Forghani, F. 2013. Effect of garlic and thyme extracts on growth performance and carcass characteristics of broiler chicks. Journal of Animal Science Technology. 54: 185-190.

Ayeni, O. E., Alokan, J. A. and Onihi, G. E. 2008. Performance and meat quality of broiler chickens fed diets containing supplementary garlic (Allium sativum). Federal University Technology. Akure.

BIS. 1992 Indian Standard: Poultry Feed Specifications. 4th Revision. Bureau of Indian Standards, New Delhi.

Bone, F.J. 1979. Anatomy and physiology of farm animals. Reston, USA.

Chi, M. S., Koh, H. and Steward, T. J. 1982. Effects of garlic on lipid metabolism in rat fed cholesterol or lard. The Journal of Nutrition.. 112:241-248.

Elagib, H. A. A., El-Amin, W. I. A., Elamin, K. M. and Malik, H. E. E. 2013. Effect of dietary garlic (Allium sativum) supplementation as feed additive on broiler performance and blood profile. Journal of Animal Science. 3: 58-64.

Eric B. 2010. "Garlic and Other Alliums: The Lore and the Science." Cambridge, Royal Society of Chemistry. 34:152166.

Fadlalla, I. M. T.; Mohamed, B. H. and Bakhiet, A. O. 2010. Effect of feeding garlic on the performance and immunity of broilers. Asian Journal of
Poultry Science.3:182-189.

Fayad, R. H., Razek, A. H. A.; Jehan and Ouf, M. 2011. Effect of dietary garlic supplementation on performance, carcass traits, and meat quality of broiler chickens. ISAH Congress, Vienna, 15:1-4.

Issa, K. J. and Omer, J. M. A. 2012. Effect of garlic powder on performance and lipid profile of broilers. Open Journal of Animal Science. 2: 62-68.

Jafari, R. A., Jalali, M. R., Ghorbanpoor, M. and Saraei, M. R. M. 2008. Effect of dietary garlic on immune response of broiler chicks to live Newcastle disease vaccine. Pakistan Journal of Biological Science. 11: 1848-1851.

Javendel, F., Blaridshad, B., Seifarati, J., Pourrahimi, A. H. and Baniyaghoub, S. 2008. The favorite dosage of garlic meal as a feed addictive in broiler chickens ration. Pakistan Journal of Biological Science. 11: 1746-1749.

Jimoh, A. A., Olorede, B. R.; Abubakar, A., Fabiyi, J. P.; Ibitoye, E. B., Suleiman, N. and Garba, S. (2012). Lipids profile and haematological indices of broiler chickens fed garlic (Allium sativum) supplemented diets. Journal of Veterinary Advance. 2: 474-480.

Kharde, K. R. and Soujanya, S. 2014. Effect of garlic and neem leaf powder supplementation on growth performance and carcass traits in broilers. Veterinary World. 7: 799-802.

Milosevic, N., Stanacev, V., Peric, L.; Stojcie, M. D. and Veljic, M. 2013. Effects of different levels of garlic powder in the diet on production parameters and slaughter traits of broiler chickens. Arch. Geflugelk. 77:254-259.

Oleforuh-Okoleh, V. U., Chukwu, G. C. and Adeolu, A. I. 2014. Effect of ground ginger and garlic on the growth performance, carcass quality and economics of production of broiler 
chickens. Global Journal of Biological Science and Biotechnology. 3: 225229.

Onibi, G. E., Adebisi, O. E., Fajemisin, A. N. and Adetunji, A. V. 2009. Response of broiler chickens in terms of performance and meat quality to garlic (Allium sativum) supplementation. African Journal of Agricultural Research. 4: 511-517.

Onu, P. N. 2010. Evaluation of two herbal spices as feed additives for finisher broilers. Biotechnology in Animal Husbandry. 26: 383 - 392.

Prasad, R., Rose, M. K., Virmani, M., Garg, S. L and Puri, J. P. 2009. Lipid profile of chicken (Gallus domesticus) in response to dietary supplementation of garlic (Allium sativum). International Journal of Poultry Science. 8: 270-276.

Qureshi, A. A., Din, Z. Z., Abuirmeileh, N., Burger, W. C. and Elson, C. E. 1983. Inhibition of cholesterol and fatty acid biosynthesis in liver enzymes and chicken hepatocytes by polar fractions of garlic. Lipids. 18:343-348. Doi:
10.1007/BF02537229

Raeesi, M., Hoseini- Aliabad, S. A., Roofchaee, A., Zare Shahneh, A. and Pirali, S. 2010. Effect of periodically use of garlic (Allium sativum) powder on performance and carcass characteristics in broiler chickens. World Academy of Science, Engineering and Technology. 68: 1213- 1219

Rahmatnejad, E., Roshanfekr, H., Ashayerizadeh, O., Mamooee, M. and Ashayerizadeh, A. 2009. Evaluation the effect of several non-antibiotic additives on growth performance of broiler chickens. Journal of Animal and Veterinary Advances. 8: 16701673.

Tsao, S. M. and Yin, M. C. 2001. In vitro activity of garlic oil and four diallylsulfides against antibiotic resistant Pseudomonas aeruginosa and Klebsiella pneumoniae. Journal of Antimicrobial Chemotherapy. 47: 665670.

\section{How to cite this article:}

Bondona Borgohain, Joga Dev Mahanta, Deben Sapcota, Bornalee Handique and Rafiqul Islam. 2019. Effect of Feeding Garlic (Allium sativum) on Haematological, Serum Biochemical Profile and Carcass Characteristics in Broiler Chicken. Int.J.Curr.Microbiol.App.Sci. 8(10): 492-500. https://doi.org/10.20546/ijcmas.2019.810.054 